\title{
Discontinuism and Its Discontents
}

\section{Martin Hewson}

University of Regina

\begin{abstract}
Discontinuism is an approach to thinking about macrohistory and large-scale change. This essay analyses and evaluates it, the first sustained investigation of discontinuism. Two forms or models of discontinuism are distinguished: a strong and a moderate version. It is proposed that the strong discontinuist model of history emphasizes the recency, shallow - roots, sudden appearance, distinctness, and likely impersistence of core features of the contemporary world. Examples of strong discontinuism are discussed in classical thought as well in relation to recent thinking about the macrohistory of nations, territoriality, the great divergence or rise of the West, and the international system. It is argued that strong discontinuism is flawed and untenable but moderate discontinuism is viable.
\end{abstract}

\section{INTRODUCTION}

Discontinuism is the reasonable and widely accepted idea that large changes were involved in the making of the current world and hence it is in many respects discontinuous from what went before. However, discontinuism can take strong and moderate forms. Strong discontinuism stresses the magnitude and recency of transformation (or discontinuity, rupture, caesura, epochal shift, structural change, divergence, big bang) in the making of the current world. Strong discontinuism is not excusive to any one school of thought; for example it may appear in both materialist and constructivist variants. By contrast, moderate discontinuism is considerably less preoccupied with searching for recent high-magnitude transformations, discontinuities, ruptures and the like.

Hitherto neither strong nor moderate discontinuism has been fully or properly identified, described, or assessed. In what follows, it is argued that strong discontinuism is fundamentally flawed and that moderate discontinuism is more reasonable. 
This paper is intended to contribute to the literatures which discuss long-term, large-scale continuities and changes in history and the making of the current world. Those literatures go under several differrent names including macrohistory, historical political science, world history and global history, historical sociology, historical political economy, cultural evolution, economic history, and historical international relations. At present there is in these literatures no specific debate on strong discontinuism or moderate discontinuism as a general phenomenon. It is hoped that this article will contribute to the beginnings of one.

The article is organized as follows. Section One identifies six main features of strong discontinuism and the contrasting approach of moderate discontinuism. Section Two outlines examples of strong discontinuism in classic social science, pointing to its themes in thinkers such as Marx, Polanyi, Foucault, and Wallerstein. Section Three compares strong and moderate discontinuism in relation to four major issues: the rise of nations and nationalism, the place of territoriality in history, the great divergence or rise of the West, and the evolution of the modern international system. In each of these areas, influential schools of thought follow closely the basic template of strong discontinuism.

\section{STRONG DISCONTINUISM VERSUS MODERATE DISCONTINUISM}

Two models of discontinuity may be distinguished, a strong and a moderate one. Although there are many variations on the theme of strong discontinuism, it generally tends to emphasize six themes or theses.

First is the short history or recency thesis. Strong discontinuism portrays much in the current world as having a short history or having been recently invented. Conversely it tends to downplay or deny that important features in the modern world are built upon longstanding or old foundations. Second is the shallow roots notion. Strong discontinuism characteristically tends to hold that key features of the contemporary world have shallow rather than deep roots. Shallow roots refer to causes, conditions or bases that are some combination of: recent in appearance, highly contingent, regarded as easy to alter, and relatively mutable. It denies that they have deep roots, that is causes, conditions, or bases that are built on longstanding, necessitous, hard to alter, and relatively immutable foundations or preconditions. Third, strong discontinuism tends to the notion that important features of the current world appeared suddenly, often unexpectedly, rather than gradually, cumulatively, or slowly. Fourth is the transformation thesis. Strong discontinuism holds that important elements in today's world arose through high-magnitude, large-scale change. In other words, 
strong discontinuism contends that transformation, discontinuity, epochal shift, singularity, caesura, rupture, reversal, or big bang is the paradigmatic way that important features of the world arise. Fifth, strong discontinuism commonly views the current era as highly discontinuous from what came before. History, it implies, is divided into clearly delineated epochs, ages, or eras and in particular the modern world is a distinct epoch. Such epochs are sharply delineated because they are bounded at start and finish by sudden, swift transformations. Strong discontinuism tends therefore towards sharp before - versus after dichotomies or presence - absence binaries. Sixth and finally is the temporary thesis. That which is new, shallow-rooted, and arose suddenly is likely to be transient rather than persistent. Strong discontinuism characteristically contends that key features of the current world are impermanent, liable to be overturned or be superseded.

In sum, strong discontinuism is a combination of all or most of these six ideas. If a theory contends that some feature of the current world is recent, shallow-rooted, arose suddenly, in a major transformation, exists in a distinct era, but is likely temporary, then it is an example of a strong discontinuist approach. Strong discontinuism can exist in both social constructivist and materialist versions according to whether discourse, culture, language, imagination, invention, or performativity on the one hand or material interests and constraints on the other hand are regarded as crucial.

Moderate discontinuism argues that even novel and discontinuous features of the world do not arrive abruptly from a tabula rasa, but instead they are built upon long histories, deep roots, and are likely persistent. Moderate discontinuism is an approach to understanding macrohistory that rejects the six key themes of strong discontinuism. First, it rejects the recency thesis for a long history thesis. Moderate discontinuism would consider the current world as an assemblage of many components: some of them have a short history, but others have a long history. Some of main features of the world are not entirely new arrivals on the scene but arose from an old rootstock, which affected their later shape. Second, it rejects the shallow roots thesis for a deep roots thesis. For moderate discontinuism, among the many components of the world, at least some of their roots are deep. Third, instead of the sudden change thesis, moderate discontinuism holds that some components of the world likely arose relatively slowly, in a stepwise manner. Fourth, moderate discontinuism amends the transformation thesis to the effect that as well as major transformations, it is important to be on the lookout for continuities, evolutionary changes, and cycles. There is more to history than transformations, epochal shifts, singularities, caesurae, ruptures, or big bangs. Fifth, instead of 
the current era being highly discontinuous from earlier times, moderate discontinuism holds that there is some overlapping of the epochs. Sixth, moderate discontinuism emphasizes not just temporary nature of things but also the persistence of some things. If important components of the current world are relatively old and deeply rooted, they are likely to be persistent or sticky, that is unlikely to easily, or completely, or permanently disappear in a future discontinuity.

Strong discontinuism as presented above is an ideal - type or a model, deliberately simplifying complexities. Yet, as will be shown in the following sections, it is remarkable how closely many influential bodies of theory follow the template.

\section{STRONG DISCONTINUISM IN FOUR KEY THINKERS}

This section presents evidence that strong discontinuism is a major theme in four of the most influential thinkers of modern social science: Marx, Polanyi, Foucault, and Wallerstein. Their versions of strong discontinuism are outlined and it is pointed out how a moderate discontinuism would differ.

There are many strands to classical Marxism, but one displays all of the main hallmarks of strong discontinuism. Marx thought of capitalism as recent; as shallow-rooted; as having arisen in a sudden transformation, and as temporary. Capitalism is recent: classical Marxism argued that, following a transition period known as 'primitive accumulation', capitalism proper only dates from about the nineteenth century. Capitalism's roots are shallow: it is neither rooted in any natural desire to exchange, nor in a natural desire for property. The power of the bourgeoisie is the principal root of capitalism. The rise of the bourgeoisie created capitalism, the bourgeoisie sustains capitalism, and the overthrow of the bourgeoisie will end capitalism. Capitalism is highly discontinuous with what went before: as a distinct mode of production, capitalism differs from all previous modes. Modes of production partition history into distinct epochs. Capitalism's origins were in a sudden transformation: classical Marxism regarded the bourgeois revolutions notably the Dutch revolt, the English Glorious Revolution, and the French Revolution as its genesis. Capitalism's likely lifespan is short: classical Marxism expected capitalism to be replaced in comparatively short order.

By way of contrast, moderate discontinuism would offer a quite different account of the place of capitalism in history. It would count (as did Weber and Braudel) some aspects of capitalism as old, even as other aspects are recent; it would doubt that capitalism has only shallow roots and is not built upon the foundation of widespread desire for ex- 
change and property; it would point out that far from being temporary, capitalism has proven to be comparatively persistent and resilient.

Karl Polanyi's The Great Transformation (1957) is an enduring classic of political economy with a narrative about the rise and fate of market society that continues to be widely cited. Polanyi's approach is steeped in strong discontinuism. He strongly advocates the short history thesis. It is a keystone of Polanyi's thought that market society arrived only very recently, in the nineteenth century. Previously, he argued, markets had a very limited role. In his words, "no economy prior to our own was even approximately controlled and regulated by markets' while gain and profit on exchange 'never before played an important part in human economy' (Polanyi 1957: 44).

The shallow roots argument was also important in Polanyi's account. According to Polanyi, market society was the artificial creation of government legislation in nineteenth-century Britain. Laissez-faire was enacted by the state, not rooted in any deep desire for liberty, or in civil society, or in prevailing individualism, or in social trust, or in any other deeper feature of society. Here is how Polanyi expresses the notion:

There was nothing natural about laissez-faire; free markets could never have come into being merely by allowing things to take their course ... laissez-faire itself was enforced by the state. ... The road to the free market was opened and kept open by an enormous increase in continuous, centrally organized and controlled interventionism (Polanyi 1957: 139-141).

Furthermore, market society arrived in a sudden Great Transformation. Polanyi gave a bipolar character to history: before, markets had been 'embedded' and of negligible importance; afterwards markets were disembedded and the dominant influence on society. For Polanyi, there is a stark before and after contrast. Before the great transformation, markets did not govern economic activity. Economic activity was governed by social principles of reciprocity or redistribution, that is by cooperation whether voluntary or enforced by authority. Afterwards, the logic of the market ruled. Before, land, labour and money were not commodities. After, they were. Before the great transformation people were motivated by desire for subsistence. Afterwards, they became motivated by greed and individual gain: '[t]he transformation implies a change in the motive of action on the part of the members of society: for the motive of subsistence that of gain must be substituted' (Polanyi 1957: 41). Even basic human motivations were transformed. 
In line with the fourth pillar of strong discontinuism, Polanyi depicted market society as necessarily temporary. Polanyi coined a concept to describe this impermanence: the 'double movement.' The attempt to impose free markets stimulated a movement of self-defence by society to limit or control the market. Market society, he thought, was self-undermining, or self-destructive, and could not last. These similarities explain why Polanyi, who was not a Marxist because he shunned class analysis, is nevertheless close to Marxism and frequently admired by neo-Marxists. This is how he expresses the temporary argument: 'the idea of a self-adjusting market implied a stark utopia. Such an institution could not exist for any length of time without annihilating the human and natural substance of society' (Polanyi 1957: 3). In similar words: 'To allow the market mechanism to be the sole director of the fate of human beings and their natural environment ... would result in the demolition of society' (Polanyi 1957: 73). As a consequence, there was soon a reaction against the market. 'Social history in the nineteenth century was thus the result of a double movement ... Society protected itself against the perils of a selfregulating market system ...' (Polanyi 1957: 76).

In contrast, a moderate discontinuism would point out that Polanyi was unreasonably sceptical about the existence of markets before the nineteenth century; that he implausibly supposed that a market society could be brought into existence by the state in an act of ab nihilo creationism rather than being built upon earlier deeper foundations; and that he prematurely concluded that market society had been a temporary interlude rather than a persistent, albeit continually modified, presence.

Michel Foucault's ideas have been among the most influential of any social theorist of the past half century. His thought is permeated with strong discontinuism. In the conclusion to The Order of Things: An Archaeology of the Human Sciences he declares: 'As the archaeology of our thought easily shows, man is an invention of recent date. And one perhaps nearing its end. ... If those arrangements were to disappear as they appeared, ... then one can certainly wager that man would be erased, like a face drawn in sand at the edge of the sea' (Foucault 1966/1970: 386). This passage is a distillation of strong discontinuism. 'Man' is said to be recent, to have shallow roots (invented out of nothing by the discourse of the human sciences), to have appeared suddenly in a transformation, and is likely to be as temporary as an image on the beach.

The great discontinuity, according to Foucault, was the Enlightenment. His thinking was counter-Enlightenment in cast: he scorned humanism, relativized science as one discourse among many, and portrayed rationality as oppressive. Here is how he characterizes the re- 
sults of the Enlightenment in an interview: 'In actuality out of this philosophical vision - the vision of a non-alienated, clear, lucid and balanced society - industrial capitalism emerged, that is, the harshest, most savage, most selfish, most dishonest oppressive society one could possibly imagine. ... More importantly this monstrosity we call the state is to a great extent the fruit and result of their thinking' (Foucault 1978/2005: 185). The Enlightenment and its manifold creations was his foe.

All of the pillars of strong discontinuism are apparent in Foucault. The recency thesis is prominent: a theme of Foucault's is that his various objects of inquiry are recent. A modern 'episteme' (system of thought) originates around 1800, with the Enlightenment. In The Order of Things, he announces that 'man did not exist' (Foucault 1966/1970: 308) until the nineteenth century. In Discipline and Punish, he emphasizes that the 'carceral archipelago,' which he claims produces 'docile bodies' (Foucault 1977: 298) by discipline and surveillance in prisons, schools, and factories arises only after about 1800 .

Also, the shallow-roots thesis is there. Foucault gave the impression that these things are shallow-rooted. In the Archaeology of Knowledge (Foucault 1972), one 'episteme' or system of thought tips over into another by no great cause so the modern episteme appears to lack any substantial roots. In the Foreword to the English translation of The Order of Things, Foucault admits that he made no attempt to explain the reasons why there was a change from the classical to the modern episteme: 'In this work, then, I left the problem of causes to one side; I chose instead to confine myself to describing the transformations themselves' (Foucault 1970: xiv). This lack of explanation conveys the impression that the modern episteme is accidental, that it appeared without need of any major causation, and is thus shallow rooted. The History of Sexuality Volume One adopts the theme that contemporary forms of sexuality arise not from the deep roots of evolved mating strategies but from the shallow roots of modern discourses about sexuality (Foucault 1988). One of the notable absences in all of Foucault's works is that for all his preoccupation with the Enlightenment (and its alleged monstrous and oppressive effects), he gave little or no attention to the Enlightenment's origins and roots.

Foucault followed the strong discontinuist thesis of emphasizing ruptures or fundamental breaks. He commonly calls them epistemic breaks. This theme is common to both his early 'archaeology' period and his late 'genealogy' period. There are in his works ruptures from one idea of madness to another, from one episteme to another, from one mode of power/knowledge to another, from one form of punishment to another, from one discourse on sexuality to another, from one mode of 
governmentality to another. These ruptures all happen suddenly. And they bring massive changes despite happening in an instant. The background infra-rupture is the Enlightenment, treated as a sudden transformation, rather than a cumulative development.

The temporary thesis is strong in Foucault's work. He was prone to giving the impression that the modern episteme (and its various manifestations) would be temporary - like a face inscribed on the sand about to be erased by the waves. Foucault consistently de-valued Enlightenment thinking. Instead, at various times he valorised avantgarde literature, madness, ancient Greek writings on self-control, the Iranian revolution, and so-called limit-experiences. It seems reasonable to conclude that he had no consistent, clear or convincing idea of what alternative was supposed to follow the Enlightenment except the notion that if the Enlightenment appeared recently and suddenly out of the blue, so might it disappear in the same way.

As against Foucault's strong discontinuism, moderate discontinuism would doubt that all important Enlightenment values and ideas (or discourses) are new creations of around 1800 and that they had no earlier origins or foundations; nor would it agree that they are so shallow-rooted as to be produced by discourse alone, or as to be erasable like a face in the sand; nor would it accept that they turned out to be quite as temporary as Foucault was anticipating half a century ago.

Wallerstein's $(1995,2004)$ world-system analysis is, among other things, strongly discontinuist. According to Wallerstein, the "worldsystem' is a relatively recent innovation, no more than several centuries old. Wallerstein dates it to the long sixteenth century (1450-1650) with the advent of transatlantic trade and European colonies. The world system has very shallow roots. For Wallerstein it is rooted in long-distance trade, specifically trade in necessities not luxuries. In world-system analysis, the presence of international trade alone is sufficient to create an all-encompassing, homogenous, worldwide 'system' which determines everything which goes on within every nation, including its level of development, its wealth and its power. For Wallerstein the system arose suddenly and is highly discontinuous from what went before (and what will come after). Previously there had only been 'world empires' and 'mini-systems', never before had there been a capitalist worldeconomy. This means that history is divided into segregated epochs. So segregated are the epochs that Wallerstein insists that once the system arises there are no feudal regions within it, nor socialist regions within it. Hence his notorious claim that the USSR was actually capitalist. There is no overlap between different eras of history. Finally, Wallerstein posits that the capitalist world-system is temporary. He has argued that we are living in an era of transition to a future discontinuity 
which will create what Wallerstein calls a 'socialist world-government.' Wallerstein (1998) thinks that capitalism has only another 50 or so years left in it.

By contrast, moderate discontinuism depicts a very different view of the world-system. To begin with, it would point out that longdistance trade (and hence the world-system) has ancient rather than recent origins, as several world-system analysts have themselves come to argue (Abu-Lughod 1991; Frank and Gills 1993). Long-distance trade is not as new as Wallerstein's strong discontinuism needs it to be. Also, moderate discontinuism would be unsatisfied with the notion that a world-system (inasmuch as a coherent system exists) is rooted in simply than long-distance trade. Given these differences, the worldsystem is unlikely to be as temporary as Wallerstein anticipates.

To conclude this section, strong discontinuism is a prominent feature of several of the most influential social scientists of recent times. Once the thought of Marx, or Polanyi, or Foucault, or Wallerstein is seen in this light, considerable illumination is shed upon the meaning and intention of their ideas. In the next part, it will be seen that strong discontinuism is to be found in several noteworthy areas.

\section{STRONG DISCONTINUISM AND NATIONS}

Strong discontinuism is particularly influential in the theory of nations and nationalism, where is known as 'modernism'. Modernism came to be main perspective on nationalism from the 1980s onward (Smith 1998; Ichijo and Uzelac 2005). Modernists, as the name suggests, regard the nation as a recent invention, born from the late eighteenth century onwards; arising from a tabula rasa not building upon the base of earlier forms of ethnicity or nationhood; a product of shallow roots such as capitalism or industrialism; and a feature of a discrete and discontinuous epoch dominated by nations in contrast to the earlier epoch without any nations. Some of the most famous works of social science are modernist works on nationalism (e.g., Gellner 1983; Anderson 1983).

The modernist theory of nations follows closely the template of strong discontinuism. Nations and nationalism are recent. Gellner (1983) does not give a precise dating, but he thinks nations exist only after about 1800. According to Anderson, the nation was 'born in an age in which Enlightenment and Revolution were destroying the legitimacy of the divinely-ordained, hierarchical dynastic realm' (Anderson 1983: 7). Modernists insist on the novelty of nations. They also regard the era of nations as having shallow roots. Nations, they agree, do not have deep roots in shared ethnicity or ancestry. Hobsbawm (1990) dismisses the influence of what he calls 'pre-existing cultures'. He writes as if nations can be brought into being from any substrate: 
'Nationalism, which sometimes takes pre-existing cultures and turns them into nations, sometimes invents them, and often obliterates preexisting cultures: that is a reality' (1990: 10). Gellner contends the nation is rooted in industrialism. Industrial society needs a uniform literate culture so cultures and states need to be congruent with one another. Anderson thinks the root of nations is, in his famous phrase, 'imagined communities.' A nation can be imagined into being. Print capitalism assisted this process. Overall, modernists point to one or another feature of modernity - capitalism, industrialism, mass education, secularization, mass conscription, and the mass politics of the modern state - as the root of nationality. Nations, they argue, can be built by these mechanisms from any raw material, not on the foundation of old pre-existing ethnics or nationalities.

The advent of nations appears to the modernist as discontinuous and sudden: the world went from being devoid of nations to their being ubiquitous comparatively quickly. Hence for the modernists there is a very sharp contrast between an era before nations and the era of nations. Before, peasant masses had only local or religious identities, elites had imperial identities. Before, the world is composed of dynastic states, universal religions, and illiterate peasants. At the close of Nations and Nationalism, Gellner employs an arresting image of the discontinuity: before the advent of modernity and nations, the world was a Kokoschka painting, spots and dabs of culture, language, religion, and ethnicity were intermingled here and there, having no relation to political boundaries. After the Big Bang the world became a Mondrian painting composed of solid blocks in which culture and state were congruent. Anderson writes frequently of an 'age of nationalism' or 'epoch of nationalism' indicating he thinks of it specific delineated period, discontinuous from what went before - and from what may come after.

The major strength of strong discontinuism with regard to the nation is its proper insistence that the modern era is distinctive because nations and nationalism are of unprecedented importance. This means that some form of discontinuism is necessary. But strong discontinuism has a serious flaw. In denying the existence of premodern nations, portraying history dichotomously, and doubting that nations are rooted in and built upon pre-existing ethnicity, it oversimplifies the complexity of the nation's place in history.

Moderate discontinuism would portray the history of nations along the following lines. Firstly, not all nations are recent creations of modernity. Gellner observed in an aside while most nations are new, some are old (Gellner 1983: 138). Most importantly, there is a good correlation between regions which had nations in premodern times (East Asia, Europe) and those that have strong nations in mo- 
dernity, while regions without nations in premodern times (Middle East, Africa) are also the areas without strong nations in modern times (Hastings 1997; Lieberman 2009; Gat 2012). This is consistent with the claim that nations are rooted in, and products of, not just modernity but deeper phenomena particularly common ethnicity (Smith 1986), common religion, and attachment to homeland or territory (Grosby 1995b). This explains why 'nation-building' is difficult. Nations are not conjured into existence from a tabula rasa but built from preexisting foundations. Hence it is unreasonable to posit a discontinuous division of history into an age before nations and an age of nations.

Strong discontinuism has made its mark not only in the study of nations but also the study of ethnic fractionalization. It argues that the kind of ethnic fractionalization to be found especially in postcolonial countries is recent, and is shallowly rooted in the effects of European colonialism. Prior to colonialism in Africa, the argument goes, identities were fluid. Modern colonialism solidified these once-fluid identities and thereby created the ethnic fractionalization common throughout the post-colonial world. A classic instance of this argument is by Ranger (1983) who, in the influential book The Invention of Tradition (Ranger and Hobsbawm 1983), argued that many African traditions, including ethnic identities, seemingly age-old, had been invented by colonial authorities comparatively recently.

However, this argument, which fits the strong discontinuism template, is open to criticism by the arguments of moderate discontinuism. Ranger (1993) revisited his own argument and concluded that the notion of 'invention' was simplistic and misleading. Reid (2011) criticized the tendency to foreshorten African history by emphasizing the colonial period as the crucible of ethnic identities rather than the pre-colonial. Kaufmann tests modernist or strong discontinuist theory with regard to ethnic fractionalization (EF) or the level of ethnic diversity among countries. His conclusion is that 'cross-national differences in EF are largely rooted in the geography, climate and historical institutions of a country. Ethnic diversity broadly predates modern political and economic change' (Kaufmann 2015: 208). Kaufmann's results are consistent with the view that ethnic diversity is not recent, shallow rooted in modern colonialism, or new. It is consistent with a moderate discontinuism.

Strong discontinuism has also been applied to Indian caste. Dirks (2001) portrays caste as recent and a product of shallow roots in British colonialism. Dirks says his aim is to show the 'historicity of caste' and Part One of his book on the subject is called "The "Invention" of Caste'. Colonialism invented or socially constructed caste particularly through the Indian census and the efforts of scholars to produce eth- 
nographies of caste. According to Dirks 'colonialism in India produced new forms of society that have been taken to be traditional ... caste as we know it is not a residual survival of ancient India but a specifically colonial form of civil society' (Dirks 2015: 84). Prior to colonialism, 'caste was just one category among others' (Ibid.: 88). The unmistakable template of strong discontinuism is here: caste is recent, shallow rooted (in colonialism), appeared suddenly, and represents not a long tradition but a new invention.

However, moderate discontinuism would argue that while colonialism may have affected caste, its main elements are old, deeply rooted, and persistent. A genetic analysis of Indian populations concluded: 'Some historians have argued that 'caste' in modern India is an 'invention' of colonialism in the sense that it became more rigid under colonial rule. However our results indicate that many current distinctions among groups are ancient and that strong endogamy must have shaped marriage patterns in India for thousands of years' (Reich et al. 2009: 491). This is more consistent with moderate discontinuism than with strong discontinuism.

\section{STRONG DISCONTINUISM AND TERRITORIALITY}

Strong discontinuism has been a notable influence in writings on territoriality (Ruggie 1993; Agnew 1994; Larkins 2010; Branch 2011; Kadercan 2015). The basic argument is that territoriality is a recent invention and as a modern political or social construct is comparatively shallow rooted hence it may be temporary. A widely cited example of this line of argument is Ruggie (1993) 'Territoriality and Beyond: Problematizing Modernity in International Relations.' Ruggie charges the field of International Relations with failing to address large-scale change, epochal change, or fundamental transformation. His remedy is to focus on territoriality and he advocates a strongly discontinuist interpretation of it. Ruggie proceeds to depict territoriality as comparatively new, arising from shallow roots, appearing suddenly, in a transformation that divided history into distinct non-territorial and territorial epochs, which will likely be temporary as a future post-territorial era emerges.

For Ruggie, territoriality is a novel thing dating back only as far as the early modern period in Europe. He makes no mention of older territorial entities. Ruggie also regards it as shallow rooted: it is produced by modernity. Among the main mechanisms by which modernity constructs territoriality Ruggie cites the following: the Renaissance invention of perspective, or the illusion of depth, in painting; growing commerce; property law; larger scale wars; and standing diplomacy. In short, particular contingent features of early modern Europe were its 
origins. Ruggie sees the advent of territoriality as bringing distinct epochs: formerly there was no territoriality then there was universal territoriality. Ruggie calls this a 'fundamental discontinuity,' an 'epochal' change, 'a transformation in the spatial organization of politics' (Ruggie 1993: 159). Ruggie expects it to be temporary. He points, as a possible future discontinuity, to the European Union as a potential post-modern, post-territorial, 'multiperspectival polity.' Before modernity, and afterwards, territoriality is assumed to be absent.

Ruggie made a major contribution by bringing the issue of modernity and epochal change to attention. But his account of territoriality has a major flaw: it is Eurocentric. Ruggie draws a contrast between medieval Europe, with its weak states, and modern Europe, with its strong states, as the fulcrum of territoriality. But this neglects the deep history of territoriality among states societies over the past 5,000 years, nonstate horticultural societies over the past 10,000 years, and huntergatherer societies since the Palaeolithic era. Moderate discontinuism would recognize that modern territoriality is distinctive, but would regard it as having been built upon the foundations of older forms of territoriality. This makes territoriality less recent and less discontinuous than Ruggie supposes. One possible deep root is the existence of an evolved desire to possess an exclusive territory (Ardrey 1966; Grosby 1995a). Discussing ethnic conflict over territory, Toft notes: 'ethnic groups want to control territory because it means securing their identity. A secure identity, in turn, means the group's continued existence and survival' (Toft 2003: 31). Moderate discontinuism concludes that it is more reasonable to think that instead of arriving suddenly, territoriality evolved through many phases. Instead of history being starkly divided into pre-territorial, territorial, and post-territorial epochs (coinciding with premodernity, modernity, and postmodernity) there have been various forms of territoriality in each.

\section{STRONG DISCONTINUISM AND THE GREAT DIVERGENCE}

Strong discontinuism plays an important role in prominent contemporary arguments about the great divergence, once known as the rise of the West (Grinin and Korotayev 2015). The strong discontinuist approach is very close to what Morris (2010: 13-22) calls the 'short-term accident' view, which he contrasts to a 'long-term lock-in' perspective. It emphasizes recency (that is the short-term part) and shallow roots (the accident part). Proponents of the 'short-term accident' (or strong discontinuist) argument include Frank (1998), Pomeranz (2000), Hobson (2004, 2012), Goldstone (2002, 2008), and Goody (1996, 2015). 
They argue that the West's ascent was very recent; shallowly rooted because very largely an accident; sudden; a major discontinuity from the similarity or homogeneity of Eurasia that had previously existed; and likely temporary - all hallmarks of strong discontinuism.

The 'short-term accident' approach argues that the great divergence was recent. Frank (1998: xxiv) declares 'the 'Rise of the West' came late and was brief'. Before 1800, Frank maintains, Asia dominated the world economy and China was the core of the world system. Only after 1800 or even 1830 did the West become the core. Pomeranz also argues the divergence was recent. The bulk of his important work The Great Divergence (2000) is devoted to presenting evidence that there was a similarity or parity of economic development between Europe and China, or specifically between their two most advanced areas England and the Yangzi delta, until 1800. In living standards, technology, industry, commerce, consumption, finance and more, Pomeranz argues, the lead of Europe in general and England in particular is recent, not long-established. Goldstone too holds that there was no sign of early rise, on the contrary Europe's divergence came late: 'Europe, China, India, and the Ottoman Empire were all experiencing a similar course of advanced organic development' (Goldstone 2000: 191) until about 1800.

This approach also proposes that Europe's ascendance is shallow rooted. They all deny that the West's rise was due to its deeply-rooted features. Frank (1998) strongly denies the ascendance of the West had anything to do with long term exceptional Western qualities. Instead, he argues that Europe was a lucky beneficiary of global-level processes that undermined the position of Asia. Europe took advantage of a temporary down cycle in the world system for Asia. Europe's motive was to catch-up, to seek access to riches of Asia. Europe's means of doing this was South American bullion. Thus superficial causes - a downturn in Asia, desire to catch-up, and lucky possession of silver and gold were behind the rise of the West. Pomeranz also rejects that the great divergence is rooted in longstanding distinctive feature of the West. Pomeranz sums up his argument by saying that 'coal and colonies' (Pomeranz 2000: 68) were the crucial factors. Britain's luck in having windfall resources is what distinguished it from China. Britain had coal and colonial resources, especially cotton, which China lacked. In other words, fortune, that most shallow of causes, is the root. Europe was a 'fortunate freak' (Ibid.: 207). Goldstone too emphasizes the shallowest of factors: the West's rise was due to 'chance events' not 'long standing prior differences' (Goldstone 2000: 191); it was the 'most freakish of accidents' (Ibid.: 187). Hobson too appeals to shallow roots. One was luck: 'In one sense the rise of the West could in- 
deed be explained almost wholly through contingency' (Hobson 2004: 313). A second shallow root was borrowing: the West imitated and adapted the technologies, institutions, and inventions of Asia. Almost every achievement of the West, according to Hobson, was indebted to borrowing from Asia. The interconnection of Eurasia, which Hobson calls 'oriental globalization', was 'the midwife, if not the mother, of the medieval and modern West' (Ibid.: 36).

In this perspective, the divergence was sudden. This is one reason why the term 'great divergence' is now favoured. The older term 'rise of the West' implies a longer more gradual process extended over many centuries. A divergence implies a brief switch over a few decades. The divergence was a significant discontinuity from what previously existed: either a reversal from European backwardness and peripherality, or a reversal from Eurasian homogeneity and parity to divergence and disparity. Frank depicts it as a 180-degree reversal: before 1800, the West had been peripheral, and China had been the core. Europe was 'marginal, far-off peninsular position on the map' with a 'minor role in the world economy' (Frank 1998: 324). From being a peripheral backwater, the West flipped to became the core. Pomeranz emphasizes a sharp binary disjuncture between before and after. Before, there was Eurasian similarity. After, there was Western dominance. Before, the West was not unique, or exceptional, or divergent, or rising. Only after did it diverge in any way. Before, there was parity, afterwards there was not. Hobson too sees a reversal: before, Asia was more advanced and dynamic and Europe was backward and stagnant. Hobson (2004) emphasizes the impressive achievements of China in particular but also Islam, Southeast Asia, India, and Japan while also underlining the backwardness of Europe. The East, he argues was advanced and dynamic. The West was backward and stagnant. The transformation was a reversal of polarities. Thus in this 'short-term accident' approach history divides into sharply distinct epochs: an Asian Age (Frank), or an era of oriental globalization (Hobson), or an age of Eurasian parity (Pomeranz) which suddenly ended and gave way to a very different modern era.

An implication is that West's ascendance is temporary. In Frank's account, if a core can shift that suddenly, on such shallow causes, then there could be a future discontinuity with the West swiftly dethroned something that Frank as a critic of the West would strongly welcome. If the periphery and core can flip places, then another 180-degree reversal would see the West as the periphery and Asia as the core.

The 'short-term accident' view has achieved much in pointing out that Western Europe had numerous similarities with parts of Asia, especially China, until comparatively late (Daly 2014). But moderate discontinuism would contend that it is flawed by its overly strong dis- 
continuism. Firstly, moderate discontinuism would argue that the divergence was complex, with more than a single late divergence; instead there were several divergences before 1800 including the scientific revolution and the origin of the constitutional state (Andrade 2016; Daly 2013). Some divergences were early, others were comparatively recent. In addition, this means that the image of a sudden, sharp discontinuity from the previous Eurasian homogeneity is exaggerated. Given this it is unreasonable to think that this complex set of divergences could have a shallow root such as an accident. Inasmuch as there is a complex set of several divergences, then it would be sensible to suppose that while some may prove to be temporary, others may prove to be persistent. In short, moderate discontinuism regards the idea of late or short-term, accidental, single divergence unrealistic.

\section{STRONG DISCONTINUISM AND THE INTERNATIONAL SYSTEM}

A number of theories of the international system are founded upon strong discontinuism. Among them are three influential approaches: (a) certain Marxist theories of the international system; (b) the idea of a Westphalian system; and (c) the idea of a nineteenth century transformation to the modern international system. This section examines these notions and compares them with moderate discontinuism.

\section{Strong Discontinuism in Marxist Conceptions of the International System}

Marxism lends itself to a strong discontinuist understanding of the international system. A standard Marxist perspective (e.g., Rosenberg 1994) is that the international system has a short history (coeval with the recent advent of capitalism), shallow roots (it is a product of capitalism being part of the superstructure of the capitalist mode of production), originated in a transformation (the transition to capitalism), is highly discontinuous with what went before (just as capitalism is highly discontinuous from pre-capitalist modes of production), and is temporary inasmuch it potentially will end in another shift (the transition from capitalism to socialism).

Wallerstein's $(1995,2004)$ world-system analysis exemplifies the strong discontinuist model. In Wallerstein's approach the interstate system (as he calls it) is only a relatively recent feature of history. It has existed only since the advent of the world-capitalist system in the sixteenth century. It is destined to be temporary, soon to be replaced by a 'socialist world-government.' The interstate system has shallow roots. It exists only because it is functional for, that is needed by, the 'capitalist world-economy.' The root of the international system lies, 
according to Wallerstein, in the need of the capitalist world-economy to resist being turned into a redistributionist world-empire. It is very different from what existed before. Prior to the advent of the modern world-system there was no interstate system, only world-empires.

In contrast to world-system analysis, Political Marxism has moved away from strong discontinuism and towards moderate discontinuism. Rosenberg (1994) had once defended the Marxist version of strong discontinuism. But Rosenberg (2013) adopts a moderate discontinuism. He accepts that 'the international' or 'political multiplicity' has a long history stretching back at least as far as the dawn of settled agriculture. It is not shallowly rooted in capitalism but is deeply rooted in the perennial phenomenon of uneven and combined development, i.e., the phenomenon that heterogeneous societies interact and mutually influence with each other. Thus it did not spring forth in a quantum leap - and nor is it likely to be superseded in another quantum leap. Teschke (2003) and Lacher (2006) acknowledge that the international system antedates the rise of capitalism hence they relax the recency thesis. Because the international system and capitalism did not appear together in one moment of creation, there was no comprehensive discontinuity. As Teschke puts it, 'no single event or date can be unequivocally singled out as the decisive system-wide caesura of interstate modernity. There was no 'structural rupture' that divided premodern from modern inter-state relations' (Teschke 2003: 250).

The movement towards moderate discontinuism brings these versions of Political Marxism into closer proximity to realism. Realism is compatible with moderate discontinuism. A realist can accept that elements of the international system are recent alongside elements that are ancient; that some of its roots are shallow while others are deep; that instead of a single structural rupture dividing pre-modern from modern inter-state relations there was a succession of changes; and that the international system is not a temporary interruption in history.

\section{Strong Discontinuism and the Idea of a Westphalian System}

The term 'Westphalian system' (or 'Westphalian order'), Schmidt (2011) says, began to be used in the late 1960s, but took off in academic popularity during the 1990s. Proponents of liberalism, of critical theory, and of constructivism have been the most likely to employ the idea of a Westphalian system. Among the main theorists who have called the international system a Westphalian system are Zacher (1992), Cox (1992), Held (1995), Linklater (1998), Falk (2002), and Wendt (2003).

The notion of a Westphalian system brings along a connotation of strong discontinuism. First, it implies that the international system is 
relatively recent, existing only since time of the Westphalian settlement in the mid-seventeenth century. Second, it implies that the international system has shallow roots, having been generated either by a particular peace agreement, or by a particular set of institutions created around the time of that peace settlement. Third, it implies a sudden change in a compressed period of time produced the international system. Fourth, it implies that history is segmented into separate opposed epochs or stages: a pre-Westphalian era and a Westphalian era. Finally, it can be taken to imply that the current international system is impermanent, as the Westphalian period may be in time superseded by a post-Westphalian one.

Because of this connotation of strong discontinuism, moderate discontinuism would doubt the value of the 'Westphalian system' concept. As a complex entity, it is likely that some parts of the international system date to the Westphalian era, but other parts are older, and still other parts originated more recently. The term 'Westphalian' obscures this complexity. Moreover, moderate discontinuism would not share the view that the current international system is rooted solely in a particular treaty, or that it is rooted in an institutional arrangement analogous to that of a treaty. And it offers an oversimplified idea of history of successive discontinuous stages in a simple advance from a preWestphalian to a Westphalian to a post-Westphalian configuration, whereas actual change is more complex. As for the notion of a transformation at or around the time of Westphalia, that has proven elusive. Nexon concludes his book on the subject of international change in the sixteenth and seventeenth centuries by saying that it was "not a "watershed" or "revolutionary" moment' (Nexon 2009: 265). The religious conflict of the era was more an interruption than a transformation. Dynastic empires continued to exist. Though there were changes at that time (Sofer 2009), it is hard to detect any signal of a single, transformative, early modern discontinuity.

\section{Strong Discontinuism and the Idea of a Modern Global Transformation}

The influence of strong discontinuism about the international system can be found in Buzan and Lawson's The Global Transformation: History, Modernity and the Making of International Relations (2015). This work, which argues that the current international system was produced via a global transformation in the nineteenth century, has attracted considerable attention (Reus-Smit 2016; Musgrave and Nexon 2016; Anievas 2016; Bilgin 2016; Braumoeller 2016; Owens 2016; Phillips 2016).

Buzan and Lawson exhibit all the main traits of strong discontinuism. They think the current international system has a very short histo- 
ry. It begins in the nineteenth century. They hold it begins then because that is when (they contend) modernity begins, which they describe as a new 'mode of power' involving industrialism, rationalbureaucratic states, and ideologies of progress (Buzan and Lawson 2014: 72-75). This new 'mode of power' both connected the world more tightly than ever and altered the relations between the West and other regions. Buzan and Lawson further portray the international system as having shallow roots. International relations is not deeply rooted in the existence of separate polities, i.e. in geopolitical fractionalization, but shallowly rooted in modernity conceived as the currently prevailing 'mode of power'.

The advent of modern international relations was sudden: completed within a century. The new epoch ('modernity') is depicted as highly discontinuous with what came before: one of their aims is to persuade international relations to follow sociology in accepting a premodern-to-modern binary with the turning point located in the nineteenth century. The "basic disjuncture between modernity and what came before took place during the long nineteenth century' (Buzan and Lawson 2015: 65). They employ the terms 'a macrotransformation' or 'an epochal shift' (Ibid.: 17) but, sensing potential criticism, they are uncomfortable with the term 'big bang' (Ibid.: 32). In relying on the idea of a mode of power, they assume, without explicitly defending the idea, that history is best thought of as a succession of modes of power which are discontinuous from one another.

Moderate discontinuism would develop a different argument about modernity and international relations. Of the many elements comprising the international system, some are likely to be ancient; others may date to the nineteenth century; while still others arose even more recently. Likewise with modernity: instead of being entirely a recent invention of the nineteenth century, some aspects are older and others are newer. Neither modernity nor the international system is best conceived as having a single, recent point of origin. Both modernity and the international system have multiple start-points; some older, others more recent. Moderate discontinuism argues that the international system has deeper roots than just 'modernity' or the modern 'mode of power'. Its deep taproot is the division of humanity into different populations and their organization into separate polities. Furthermore the notion of a singularly distinctive modern 'mode of power' is questionable. It echoes the Marxian concept that history is a succession of discrete modes of production by implying that history is a succession of distinctive modes of power forming separate epochs. Moderate discontinuism would modify Buzan and Lawson's epochalism. Instead of one global transformation dividing binary premodern and modern 
epochs, it would pay attention to several changes over a long span of time. Instead of supposing that one transformation produced the international system, a more likely hypothesis is that many changes spread over many centuries made the international system.

\section{CONCLUSIONS}

This analysis points to several main conclusions. Firstly, discontinuism, the unobjectionable idea that there were large-scale changes involved in making the current world, actually appears in two forms, here called strong and moderate. This present paper is the first attempt to compare, analyze, and appraise them. A second conclusion is that strong discontinuism is remarkably influential. It has made an impact in thinking about the rise of the West, the evolution of the international system, the history of nations and nationalism, the advent of territoriality, and the development of world capitalism. Taking these together, it is one of the most influential approaches to thinking about macrohistory. Moreover, other areas too have felt the influence of strong discontinuism.

A third conclusion is that strong discontinuism follows a remarkably similar template in all its manifestations. It is astounding how writings about such diverse subjects all share a pattern without any noticeable connections between them. Fourth, although strong discontinuism has brought many insights, it is excessively one-sided and therefore flawed. It takes a reasonable idea, that there are discontinuities in history and especially in the origins of the modern world, and exaggerates or distorts it. While strong discontinuism often aims to historicize things, it turns out to deny history in the sense that it denies the extent to which later things must grow out of earlier things by developing from precursors or latent preconditions that already exist.

A fifth conclusion is that moderate discontinusm is a promising approach. The emphasis on recency, or novelty, or modernity of things needs to be balanced by a recognition that even new things have to be built upon the foundation of pre-existing things, which influences their final shape. The emphasis on the shallow roots of things is balanced by inquiring into their deep roots. Moderate discontinuism offers a more balanced assessment on how discontinuous the current world is from the past and how persistent things have been and are likely to be. Sixth, pluralism is needed in the study of macrohistory. There should be a plurality or diversity of alternative interpretive frameworks and models of macrohistory. Unfortunately, the widespread influence of strong discontinuism has tended to crowd out other perspectives and viewpoints about long-term continuity and change. It has become so widespread that it has not needed a name 
and has not always been recognized as just one perspective from among other potential approaches. To bring more diversity to macrohistory, other rival interpretive frameworks need to be brought into view, made explicit, and compared.

\section{REFERENCES}

Abu-Lughod, J. L. 1991. Before European Hegemony: The World System AD 1250-1350. New York: Oxford University Press.

Agnew, J. 1994. The Territorial Trap: The Geographical Assumptions of International Relations Theory. Review of International Political Economy 1: 53-80.

Anderson, B. 1983. Imagined Communities: Reflections on the Origin and Spread of Nationalism. London: Verso.

Andrade, T. 2016. The Gunpowder Age: China, Military Innovation, and the Rise of the West in World History. Princeton: Princeton University Press.

Anievas, A. 2016. History, Theory and Contingency in the Study of Modern International Relations: The Global Transformation Revisited. International Theory 8: 468-480.

Ardrey, R. 1966. The Territorial Imperative: A Personal Inquiry into the Animal Origins of Property and Nations. New York: Atheneum.

Bilgin, P. 2016. How to Remedy Eurocentrism in IR? A Complement and a Challenge for ehe Global Transformation. International Theory 8: 492-501.

Branch, J. 2011. Mapping the Sovereign State: Technology, Authority, and Systemic Change. International Organization 65: 1-36.

Braumoeller, B. 2016. The Promise of Historical Dynamism for the American Study of International Relations. International Theory 8: 458-467.

Buzan, B. and Lawson, G. 2014. Capitalism and the Emergent World Order. International Affairs 90: 71-91.

Buzan, B., and Lawson, G. 2015. The Global Transformation: History, Modernity and the Making of International Relations. Cambridge: Cambridge University Press.

Cox, R. W. 1992. Towards a Post-Hegemonic Conceptualization of World Order. In Rosenau, J. N., and Czempiel, E. O. (eds.), Governance without Government: Order and Change in World Politics. Cambridge: Cambridge University Press.

Daly, J. 2013. The Rise of Western Power: A Comparative History of Western Civilization. London: Bloomsbury.

Daly, J. 2014. Historians Debate the Rise of the West. New York: Routledge.

Dirks, N. B. 2001. Castes of Mind: Colonialism and the Making of Modern India. Princeton: Princeton University Press.

Dirks, N. B. 2015. Autobiography of an Archive: A Scholar's Passage to India. New York: Columbia University Press.

Falk, R. 2002. Revisiting Westphalia, Discovering Post-Westphalia. The Journal of Ethics 6: 311-352. 
Foucault, M. 1966/1970. The Order of Things: An Archaeology of the Human Sciences. New York: Pantheon.

Foucault, M. 1970. Foreword to the English Edition. In The Order of Things: An Archaeology of the Human Sciences. New York: Pantheon.

Foucault, M. 1972. The Archaeology of Knowledge. New York: Harper and Row.

Foucault, M. 1977. Discipline and Punish: The Birth of the Prison. New York: Pantheon.

Foucault, M. 1978/2005. Dialogue between Michel Foucault and Baqir Parham (1978). In Afary, J., and Anderson, K. B. (eds.), Foucault and the Iranian Revolution: Gender and the Seductions of Islamism (pp. 183-189). Chicago: University of Chicago Press.

Foucault, M. 1988. History of Sexuality, Volume One: An Introduction. New York: Vintage Books.

Frank, A. G., and Gills, B. K. (eds.) 1993. The World System: Five Hundred Years or Five Thousand? New York: Routledge.

Frank, A. G. 1998. ReOrient: Global Economy in the Asian Age. Berkeley: University of California Press.

Gat, A. 2012. Nations: The Long History and Deep Roots of Political Ethnicity and Nationalism. Cambridge: Cambridge University Press.

Gellner, E. 1983. Nations and Nationalism. Oxford: Blackwell.

Goldstone, J. A. 2000. The Rise of the West - Or Not? Sociological Theory 18: 175-94.

Goldstone, J. A. 2002. Efflorescences and Economic Growth in World History: Rethinking the 'Rise of the West' and the Industrial Revolution. Journal of World History 13: 323-389.

Goldstone, J. A. 2008. Why Europe? The Rise of the West in World History 1500 - 1850. New York: McGraw-Hill.

Goody, J. 1996. The East in the West. Cambridge: Cambridge University Press.

Goody, J. 2015. Asia and Europe. History and Anthropology 26 (3): 263-307.

Grinin, L., and Korotayev, A. 2015. Great Divergence and Great Convergence: A Global Perspective. New York: Springer.

Grosby, S. 1995a. Territoriality: The Transcendental, Primordial Feature of Modern Societies. Nations and Nationalism 1: 143-162.

Grosby, S. 1995b. Nationalism. Oxford: Oxford University Press.

Hastings, A. 1997. The Construction of Nationhood: Ethnicity, Religion and Nationalism. Cambridge: Cambridge University Press.

Held, D. 1995. Democracy and the Global Order: From the Modern State to Cosmopolitan Governance. Cambridge: Polity Press.

Hobsbawm, E. J. 1990. Nations and Nationalism since 1780: Programme, Myth, Reality. Cambridge: Cambridge University Press.

Hobson, J. M. 2004. The Eastern Origins of Western Civilisation. Cambridge: Cambridge University Press. 
Hobson, J. M. 2012. Global Dialogical History and the Challenge of NeoEurocentrism. In Bala, A. (ed.), Asia, Europe, and the Emergence of Modern Science: Knowledge Crossing Boundaries. London: Palgrave.

Ichijo, A. and Uzelac, G. (eds.) 2005. When is the Nation?: Towards an Understanding of Theories of Nationalism. New York: Routledge.

Kadercan, B. 2015. Triangulating Territory: A Case for Pragmatic Interaction between Political Science, Political Geography, and Critical IR. International Theory 7: 125-161.

Kaufmann, E. 2015. Land, History or Modernization? Explaining Ethnic Fractionalization. Ethnic and Racial Studies 38: 193-210.

Lacher, H. 2006. Beyond Globalization: Capitalism, Territoriality and the International Relations of Modernity. New York: Routledge.

Larkins, J. 2010. From Hierarchy to Anarchy: Territory and Politics before Westphalia. Basingstoke: Palgrave Macmillan.

Lieberman, V. 2009. Strange Parallels Vol. 2 Mainland Mirrors: Europe, Japan, China, South Asia, and the Islands c. 800 - 1830. Cambridge: Cambridge University Press.

Linklater, A. 1998. The Transformation of Political Community: Ethical Foundations of the Post-Westphalian Era. Cambridge: Polity Press.

Morris, I. 2010. Why the West Rules - For Now: The Patterns of History and What They Reveal about the Future. New York: Farrar, Straus and Giroux.

Musgrave, P., and Nexon, D. H. 2016. The Global Transformation: More than Meets the Eye. International Theory 8: 436-447.

Nexon, D. H. 2009. The Struggle for Power in Early Modern Europe: Religious Conflict, Dynastic Empires, and International Change. Princeton: Princeton University Press.

Owens, P. 2016. International Historical What? International Theory 8: 458-467.

Phillips, A. 2016. The Global Transformation, Multiple Early Modernities, and International Systems Change. International Theory 8: 481-491.

Polanyi, K. 1957. The Great Transformation: The Political and Economic Origins of Our Time. Boston: Beacon Press.

Pomeranz, K. 2000. The Great Divergence: China, Europe, and the Making of the Modern World Economy. Princeton: Princeton University Press.

Ranger, T. and Hobsbawm, E. (eds.) 1983 The Invention of Tradition. Cambridge: Cambridge University Press.

Ranger, T. 1983. The Invention of Tradition in Colonial Africa. In Ranger, T., and Hobsbawm, E. (eds.), The Invention of Tradition. Cambridge: Cambridge University Press.

Ranger, T. 1993. The Invention of Tradition Revisited: The Case of Africa. In Ranger, T., and Vaughan, O. (eds.), Legitimacy and the State in TwentiethCentury Africa. London: Macmillan.

Reich, D. et. al. 2009. Reconstructing Indian Population History. Nature 461: 489-494. 
Reid, R. 2011. Past and Presentism: The 'Precolonial' and the Foreshortening of African History. The Journal of African History 52: 135-155.

Reus-Smit, C. 2016. Theory, History, and Great Transformations. International Theory 8: 422-435.

Rosenberg, J. 1994. The Empire of Civil Society: A Critique of the Realist Theory of International Relations. London: Verso.

Rosenberg, J. 2013. Kenneth Waltz and Leon Trotsky: Anarchy in the Mirror of Uneven and Combined Development. International Politics 50: 183-230.

Ruggie, J. G. 1993. Territoriality and Beyond: Problematizing Modernity in International Relations. International Organization 47: 139-174.

Schmidt, S. 2011. To Order the Minds of Scholars: The Discourse of the Peace of Westphalia in International Relations Literature. International Studies Quarterly 55: 601-623.

Smith, A. D. 1986. The Ethnic Origins of Nations. Oxford: Blackwell.

Smith, A. D. 1998. Nationalism and Modernism A Critical Survey of Recent Theories of Nations and Nationalism. London: Routledge.

Sofer, S. 2009. The Prominence of Historical Demarcations: Westphalia and the New World Order. Diplomacy and Statecraft 20: 1-19.

Teschke, B. 2003. The Myth of 1648: Class, Geopolitics, and the Making of Modern International Relations. London: Verso.

Toft, M. D. 2003. The Geography of Ethnic Violence: Identity, Interests, and the Indivisibility of Territory. Princeton: Princeton University Press.

Wallerstein, I. 1995. Capitalist Civilisation. London: Verso.

Wallerstein, I. 1998. Utopistics: Or Historical Changes of the Twenty-First Century. New York: New Press.

Wallerstein, I. 2004. World-Systems Analysis: An Introduction. Durham, NC: Duke University Press.

Wendt, A. 2003. Why a World State is Inevitable. European Journal of International Relations 9: 491-542.

Zacher, M. W. 1992. The Decaying Pillars of the Westphalian Temple: Implications for International Order and Governance. In Rosenau, J. N., and Czempiel, E. O. (eds.), Governance without Government: Order and Change in World Politics. Cambridge: Cambridge University Press. 